\title{
Technical Note: Lightweight Camera Stand for Close-to-Earth Remote Sensing
}

\author{
D. Terrance Booth, ${ }^{1}$ Samuel E. Cox, ${ }^{2}$ Mounier Loubaichi, ${ }^{3}$ \\ and Douglas E. Johnson ${ }^{4}$
}

\begin{abstract}
Authors are ${ }^{1}$ Rangeland Scientist and ${ }^{2}$ Remote Sensing Technician, USDA-ARS, High Plains Grasslands Research Station, 8408 Hildreth Road, Cheyenne, WY 82009; and ${ }^{3}$ Professor and ${ }^{4}$ Research Associate, Department of Rangeland Resources, $302 B$ Strand Agriculture Hall, Oregon State University, Corvallis, OR 97331.
\end{abstract}

\begin{abstract}
Digital photography and subsequent image analysis for ground-cover measurements can increase sampling rate and measurement speed and probably can increase measurement accuracy. Reduced monitoring time (labor cost) can increase monitoring precision by allowing for increased sample numbers. Multiple platforms have been developed for close-to-earth remote sensing. Here we outline a new, $5.8-\mathrm{kg}$ aluminum camera stand for acquiring stereo imagery from $2 \mathrm{~m}$ above ground level. The stand is easily transported to, from, and within study sites owing to its low weight, excellent balance, and break-down multipiece construction.
\end{abstract}

\section{Resumen}

La fotografía digital y el subsecuente análisis de las imágenes para obtener mediciones de cobertura a nivel del suelo puede incrementar la tasa y velocidad de muestreo y probablemente la certeza de las mediciones. Reducir el tiempo de monitoreo (costos de trabajo) puede incrementar la precisión del mismo al permitir obtener un mayor número de muestras. Se han desarrollado múltiples plataformas para obtener imágenes de sensores remotos a distancias cercanas de la tierra. Aquí nosotros describimos un nuevo soporte para cámara que es de aluminio y pesa $5.8 \mathrm{~kg}$ para adquirir imágenes estereoscópicas a $2 \mathrm{~m}$ del nivel del suelo. El soporte es fácilmente transportado a los sitios de estudio y dentro de ellos debido a su bajo peso, excelente balance y su construcción de piezas plegadizas.

Key Words: rangeland monitoring, vertical, photography, nadir, digital photography

\section{Introduction}

The first use of vertical photography for plant cover analysis was reported by Cooper (1924), who used a wooden camera stand to acquire photographs of permanent plots. Between 1924 and the present, a succession of camera-stand designs have been used in the study of rangeland vegetation (Table 1). Claveran (1966) was the first of these researchers to use a camera stand for acquiring stereophotographs of quadrats. Key aspects of a successful stand design include low weight, ease of use, and simplicity. Here we present a design that combines rigidity, low weight, and balanced construction for a stand suitable for a single user working in a variety of plant communities.

\section{Lightweight Camera Stand With Quadrat Base}

For monitoring all types of rangeland, a highly portable, yet rigid, camera stand is desirable. In consultation with the

Research was funded in part by a grant from the Wyoming State Office of the Bureau of Land Management.

Mention of trade names is for information only and does not imply an endorsement.

Correspondence: D. Terrance Booth, Agricultural Research Service, 8408 Hildreth Road, Cheyenne, WY 82009. Email: Terry.Booth@ars.usda.gov

Manuscript received 6 December 2003; manuscript accepted 5 July 2004
Colorado State University Agricultural Engineering Center, we designed and constructed an aluminum camera stand similar to that described by Louhaichi et al (2001). The new stand is $2 \mathrm{~m}$ in height with a $1-\mathrm{m}^{2}$ base, constructed of $2.25-\mathrm{cm}$, thin-walled aluminum tubing with custom-milled joints (Fig. 1). The base breaks down into four $1-\mathrm{m}$ lengths and the 2 vertical poles each break down into two 1 -m lengths. Each joint has a removable pin around the base and top, permanently attached by a $10-\mathrm{cm}$ cable to one side of each joint to avoid pin misplacement (Fig. 1, upper inset). These pins allow the stand to be rapidly disassembled into nine $1-\mathrm{m}$ segments for transport and storage. The 2 segments of the 2 vertical poles are connected via a flared coupler with hand-tightened setscrews (Fig. 1, lower inset). The stand weighs $5.8 \mathrm{~kg}$, not including the camera, and is easily balanced and carried in the field by a single operator. The horizontal top bar is square in cross section. A quick-release camera mount is attached to a carriage that rolls laterally along the top bar, allowing for stereo image acquisition. Setscrews along the top bar regulate lateral movement of the mount to control the degree of parallax in the stereo imagery.

Taller features require less parallax to achieve optimal stereo effect. Too much parallax can prevent stereo viewing or lead to difficulty in focussing the images, so attention must be paid to proper adjustment of these setscrews. An Olympus E20, 5megapixel, color digital camera with infrared remote control is mounted on the camera stand to acquire nadir imagery from 
Table 1. Review of camera stands used for vertical ground photography.

\begin{tabular}{|c|c|c|c|c|}
\hline Author & Year & $\mathrm{AGL}^{1}(\mathrm{~m})$ & $\mathrm{Fld}^{2}\left(\mathrm{~m}^{2}\right)$ & Description \\
\hline Cooper & 1924 & 1.8 & 1 & $\begin{array}{l}\text { Wooden, offset tripod with all parts on } \\
1 \text { side of quadrat }\end{array}$ \\
\hline Rowland and Hector & 1934 & $N G$ & $N G$ & Wooden trestle over square meter quadrat \\
\hline Winkworth et al & 1962 & $N G$ & 2.5 & Tall stepladder \\
\hline Claveran & 1966 & 1.7 & 1 & $\begin{array}{l}\text { Metal tripod opened at top with } \\
15-\mathrm{cm} \text { wooden bars }\end{array}$ \\
\hline Wimbush et al & 1967 & 1.2 & 0.9 & $\begin{array}{l}\text { Rectangular frame supported with } \\
4 \text { spreading, detachable legs }\end{array}$ \\
\hline Pierce and Eddleman & 1970 & 1.5 & 1 & $\begin{array}{l}\text { Aluminum angle bar supported between } \\
2 \text { standard camera tripods }\end{array}$ \\
\hline Wells & 1971 & 1.3 & 1.5 & Wimbush stand modified for 2 cameras \\
\hline Tueller et al & 1972 & 2.5 & 2.3 & Tripod supporting 2 cameras \\
\hline Ratliff and Westfall & 1973 & 1.2 & 0.09 & $\begin{array}{l}\text { Square base } \sim 0.09 \mathrm{~m}^{2}, \text { camera handheld } \\
\text { against cross bar between uprights }\end{array}$ \\
\hline Pierce and Eddleman & 1973 & 1.5 & 1 & Tripod (HighBoy IV; Quick-Set, Skokie, IL) \\
\hline Owens et al & 1985 & $\leq 7$ & $\leq 6 \times 9$ & Offset tripod with adjustable camera boom \\
\hline Roshier et al & 1997 & Variable & Variable & Gantry connected to automobile \\
\hline Northrup et al & 1999 & $\leq 5.5$ & 16 & $\begin{array}{l}\text { Telescoping camera boom mounted on } \\
\text { all-terrain vehicle }\end{array}$ \\
\hline Bennett et al & 2000 & 2 & 1 & $\begin{array}{l}\text { Offset aluminum tripod with collapsible } \\
\text { camera arm, bubble levels }\end{array}$ \\
\hline Richardson et al & 2001 & 1.5 & NG & Monopod of PVC \\
\hline Louhaichi et al & 2001 & 1.7 & 3.5 & A PVC prototype of the stand described here \\
\hline VanAmberg & 2003 & 2 & 1.4 & $\begin{array}{l}\text { Wheeled, with a telescoping vertical post } \\
\text { and a } 0.5-\mathrm{m} \text { camera arm }\end{array}$ \\
\hline
\end{tabular}

${ }^{1} \mathrm{AGL}$ indicates camera altitude above ground level; Fld, field of view; NG, not given; PVC, polyvinyl chloride.

${ }^{2}$ The given field of view is that obtained by the authors using their own particular camera and lens settings.

$2 \mathrm{~m}$ above ground level (AGL). Each image covers a $1 \times 1.4 \mathrm{~m}$ area at wide-angle $(35 \mathrm{~mm})$ zoom and produces a pixel resolution of $1.16 \mathrm{~mm}^{2}$.

When sampling in tall shrub areas where it is difficult to place the 1-m quadrat base flat on the ground, sections of the stand (one vertical pole and one $1-\mathrm{m}$ base length) can be fitted together via the attached pins to create a monopod. The monopod and the attachment of a specialized aluminum camera mounting plate holds the camera $2 \mathrm{~m}$ above the ground and $1 \mathrm{~m}$ from the vertical pole allowing for easier nadir image acquisition (stereo imagery has not yet been acquired using the monopod configuration).

Shadows from tall vegetation confound many types of image analysis either by hiding areas of interest or by altering color in shaded areas. We mounted a $183-\mathrm{cm}-$ long $\times 104-\mathrm{cm}-$ wide rollup window shade along the base of the stand such that it could be pulled up and attached anywhere along the vertical side support to shade the entire plot (Fig. 1). The shade is made of mediumweight light-filtering vinyl that allows even illumination of the entire plot, eliminating shadows and providing for more saturated colors, thus improving the quality of the imagery obtained. The shade can be removed when not needed. The entire plot can be shaded except when the sun is higher than $67.5^{\circ}$. Thus, the plot can be shaded during approximately $75 \%$ of the daylight hours at an equatorial location at equinox. Northern latitudes have more daylight hours with the sun below this angle.

\section{Discussion and Conclusions}

High-resolution digital images are useful for several types of data gathering and have proven to be a quick and accurate means for vegetation classification (Bennett et al 2000; Louhaichi et al 2001). As indicated in Table 1, various types of camera stands or other ground-based platforms have been used to collect nadir imagery. Some of the more recent designs include that of Northrup et al (1999), who constructed a telescoping camera boom from aluminum channel stock and mounted it to the front of an all-terrain vehicle at $45^{\circ}$. Bennett et al (2000) constructed a portable aluminum stand equipped with a collapsible camera arm and two telescopic legs. Richardson et al (2001) used a 1.5 -m monopod made of 10-cm-diameter polyvinyl chloride (PVC) tubing, with a horizontal arm extending $1 \mathrm{~m}$ away from the top of the vertical axis. A camera mounted on the end of the arm was used to acquire nadir images in dense vegetation. Louhaichi et al (2001) mounted a $35-\mathrm{mm}$ camera on a lightweight stand of PVC tubing with the camera mounted $1.7 \mathrm{~m} \mathrm{AGL}$ and above a $1-\mathrm{m}^{2}$ base. The use of PVC as a construction material resulted in a lightweight stand $(5.1 \mathrm{~kg})$; however, PVC lacks rigidity. VanAmberg (2003) constructed a wheeled camera stand out of steel cornerstock that consisted of a $1-\mathrm{m}^{2}$ base, a single 1 - to 3-m telescoping vertical post attached to the center of a base length, and a horizontal arm projecting $0.5 \mathrm{~m}$ from the top of 


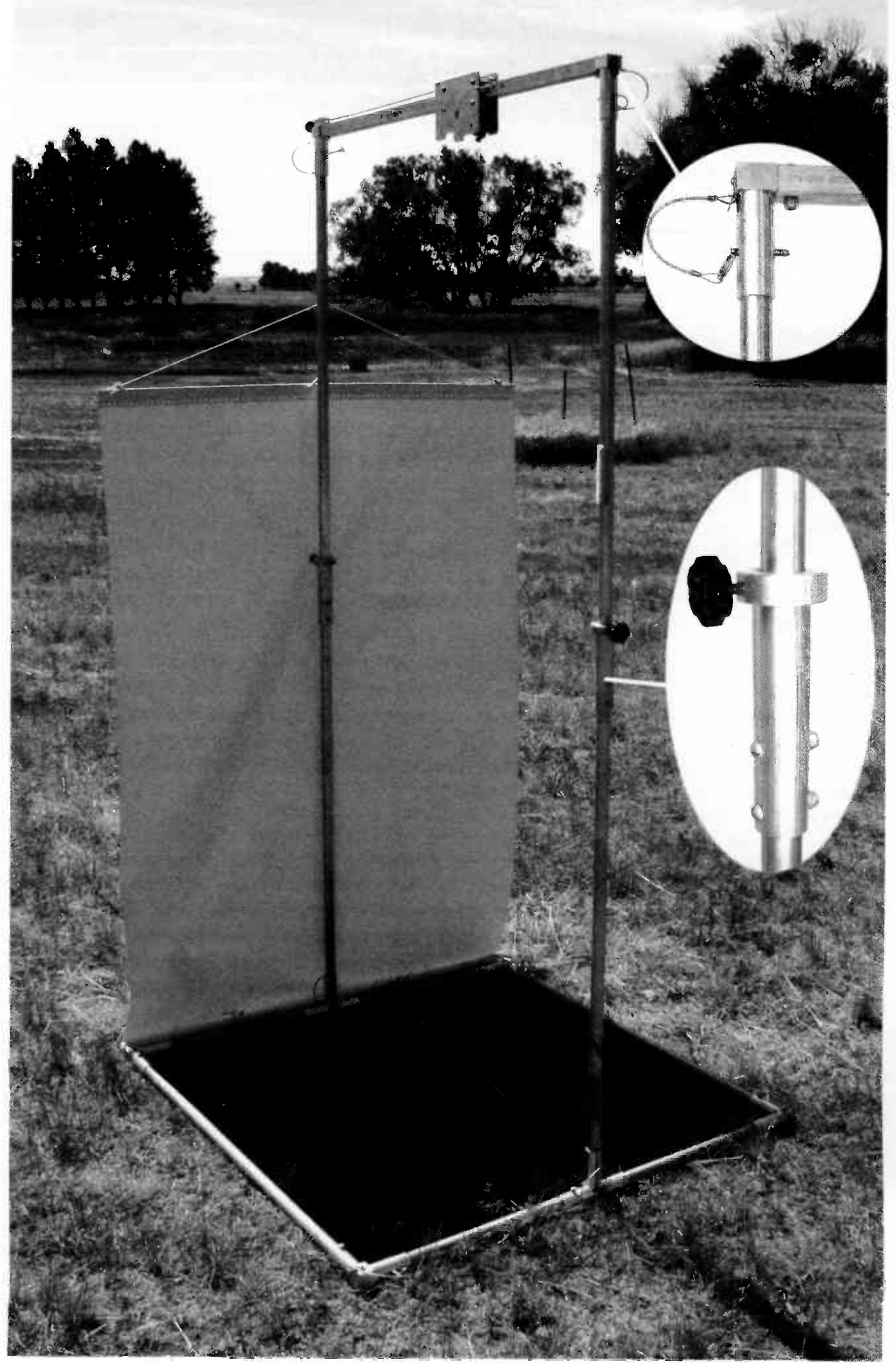

Figure 1. Aluminum camera stand with roll-up vinyl shade and shaded $1-\mathrm{m}^{2}$ plot. The stand breaks down into nine $1-\mathrm{m}$ lengths, adjusts for stereo imagery, and weighs $5.8 \mathrm{~kg}$. The base is $1 \mathrm{~m}^{2}$. The height is $2 \mathrm{~m}$. Insets show enlargements of milled aluminum connector with attached connector pin, and flared coupler with hand-tightened setscrew for vertical pole segment connection.

the vertical post to which was attached a digital camera. Although convenient for open grassland, this rolling stand is difficult to maneuver in areas with shrub cover, and it is too heavy to carry.
Construction cost for the stand described here was $\$ 250$ for materials and $\$ 390$ for labor. After more than a year of using the stand, we conclude that it is a highly practical rangeland monitoring tool with advantages that include: 1 ) the stand can 
be carried easily over uneven terrain and through most rangeland vegetation types; 2) it is stable in high-wind situations owing to its square base and rigid, durable aluminum construction; 3 ) the inclusion of the square meter frame (quadrat) as part of the camera-stand base; 4) the capability of acquiring stereo digital imagery with a single camera; 5 ) the roll-up vinyl shade allows for evenly illuminated, shadow-free, color-saturated imagery during more than $75 \%$ of the available daylight hours; and 6) the ability to break down and store the stand in a 1.1-m-long case.

\section{Literature Cited}

Bennet, L. T., T. S. Judd, And M. A. AdAms. 2000. Close-range vertical photography for measuring cover changes in perennial grasslands. Journal of Range Management 53:634-641.

Booth, D. T., S. E. Cox, And D. E. Johnson. 2004. Calibration of Threshold Levels in Vegetation-Cover Classification Software. Abstract. Society for Range Management Meeting Abstracts.

Claveran, R. A. 1966. Two modifications to the vegetation photographic charting method. Journal of Range Management 19:371-373.

COOPER, W. S. 1924. An apparatus for photographic recording of quadrats. Journal of Ecology 12:317-321.

LOUhaiChi, M., M. M. Borman, and D. E. Johnson. 2001. Spatially located platform and aerial photography for documentation of grazing impacts on wheat. Geocarta 16:63-68.

Northrup, B. K., J. R. Brown, C. D. Dias, W. C. Skelly, and B. Radford. 1999. A technique for near-ground remote sensing of herbaceous vegetation in tropical woodlands. Rangeland Journal 21:229-243.

OWens, M. K., H. G. Gardiner, And B. E. Norton. 1985. A photographic technique for repeated mapping of rangeland plant populations in permanent plots. Journal of Range Management 38:231-232.

Pierce, W. R., and L. E. Eddleman. 1970. A field stereophotograph technique for range vegetation analysis. Journal of Range Management 23:218-220.

Pierce, W. R., and L. E. Eddleman. 1973. A test of stereophotograph sampling in grassland. Journal of Range Management 26:148-150.

RatLifF, R. D., AND S. E. WeStFall. 1973. A simple stereophotographic technique for analyzing small plots. Journal of Range Management 26:147-150.

Richardson, M. D., D. E. KarCher, and L. C. PurCell. 2001. Quantifying turfgrass cover using digital image analysis. Crop Science 41:1884-1888.

Roshier, D., S. LeE, and F. Boreland. 1997. A digital technique for recording of plant population data in permanent plots. Journal of Range Management50:106-109.

RoWLAND, J. W., AND J. M. HeCtOR. 1934. A camera method for charting quadrats. Nature 133:179.

Tueller, P. T., G. Lorain, K. Kipping, and C. WilkiE. 1972. Methods for measuring vegetation changes on Nevada rangelands. Reno, NV: Agricultural Experiment Station, University of Nevada, Reno. Report T16. Available from: College of Agriculture, Biotechnology and Natural Resources, Mail Stop 22, $1660 \mathrm{~N}$. Virginia St., Reno, NV 89557-0107.

VANAMBURG, L. 2003. Digital imagery to estimate canopy characteristics of shortgrass prairie vegetation [MS thesis]. Fort Collins, CO: Colorado State University. 122 p. Available from: Deparment of Forest, Rangeland and Watershed Stewardship, The College of Natural Resources, Colorado State University, Fort Collins, CO 80523-1472.

WeLLS, K. F. 1971. Measuring vegetation changes on fixed quadrats by vertical ground stereophotography. Journal of Range Management 24:233-236.

Wimbush, D. J., M. D. BarRow, and A. B. Costin. 1967. Color stereophotography for the measurement of vegetation. Ecology 48:150-152.

Winkworth, R. E., R. A. Perry, and C. O. Rossetti. 1962. A comparison of methods of estimating plant cover in an arid grassland community. Journal of Range Management 15:194-196. 